\title{
Second-Line Treatment of NSCLC - The Pan-ErbB Inhibitor Afatinib in Times of Shifting Paradigms
}

\author{
Jens Köhler ${ }^{1,2 *}$ \\ ${ }^{1}$ Department of Medical Oncology, Dana-Farber Cancer Institute, Harvard Medical School, Boston, MA, USA, \\ ${ }^{2}$ West German Cancer Center Essen, Department of Medical Oncology, Division of Thoracic Oncology, University Hospital \\ Essen, Essen, North-Rhine Westphalia, Germany
}

OPEN ACCESS

Edited by:

Umberto Malapelle,

University of Naples Federico II,

Italy

Reviewed by:

Torsten Goldmann,

Forschungszentrum Borstel (LG),

Germany

Salvatore Lorenzo Renne, Istituto Nazionale dei Tumori (IRCCS), Italy

${ }^{*}$ Correspondence: Jens Köhler jens_kohler@dfci.harvard.edu

Specialty section: This article was submitted to

Pathology, a section of the journal Frontiers in Medicine

Received: 01 November 2016 Accepted: 20 January 2017 Published: 13 February 2017

Citation: Köhler J (2017) Second-Line Treatment of NSCLC-The Pan-ErbB Inhibitor Afatinib in Times of Shifting Paradigms. Front. Med. 4:9. doi: 10.3389/fmed.2017.00009
In contrast to the established role of epidermal growth factor receptor (EGFR) inhibitors for the first-line treatment of patients with non-small cell lung cancer (NSCLC) harboring activating EGFR mutations, the role of EGFR blockade and of EGFR molecular testing in the second-line treatment remains less clear. The irreversible pan-ErbB family inhibitor afatinib (Gi(I)otrif $\left.{ }^{\circledast}\right)$ was recently FDA- and EMA-approved for the second-line treatment of NSCLC with squamous cell histology irrespective of the EGFR mutational status (LUXLung 8). Contrariwise, results from the TAILOR and DELTA trials among retrospective biomarker analyses show the predictive value of the EGFR mutational status for efficacy of reversible EGFR inhibitors also as a second-line therapy. This mini review critically summarizes the current role of EGFR-targeting strategies in the second-line treatment of NSCLC with special respect to afatinib in light of emerging T790M-specific EGFR and immune check point inhibitors. The review also emphasizes the urgent need for reliable biomarkers to guide therapeutic decision-making and outlines prospective changes to the second-line landscape with some of the current second-line treatment concepts likely to be moved to the first-line.

Keywords: afatinib, EGFR mutation, TKI, second-line treatment, NSCLC, squamous cell carcinoma, T790M-specific inhibitors, checkpoint blockade

\section{INTRODUCTION}

Over the past decade, various genomic alterations relevant for non-small cell lung cancer (NSCLC) biology ("oncogene addiction") were discovered and have subsequently changed the treatment paradigm from a histology-oriented to a biomarker-driven approach [reviewed by Thomas et al. (1)]. Historically, docetaxel was the gold standard second-line treatment (2) until erlotinib (Tarceva ${ }^{\circledR}$ ), a first-generation tyrosine kinase inhibitor (TKI) of the epidermal growth factor receptor (EGFR) was FDA-approved in 2004 as maintenance therapy and for second and subsequent line treatment, after failure of chemotherapy in unselected patients (3). In the meantime, several phase-III trials compared EGFR TKIs with chemotherapy and have established EGFR TKIs as the standard firstline treatment for patients with EGFR-mutant NSCLC (4-7). Nowadays, not less than three EGFR TKIs-erlotinib, gefitinib (Iressa ${ }^{\circledR}$ ) and the pan-ErbB family inhibitor afatinib (Giotrif ${ }^{\oplus}$ )-are licensed for the first-line treatment. Drug reimbursement is bound to the presence of a common activating EGFR mutation (i.e., exon 19 deletions and L858R point mutations) detected by FDA-approved tests [erlotinib-cobas ${ }^{\circledR}$; gefitinib (Iressa $\left.{ }^{\circledR}\right)$ and afatinib $\left(\mathrm{Gi}(1)\right.$ otrif $\left.{ }^{\circledast}\right)$-therascreen 
EGFR RGQ]. However, the relevance of EGFR mutations for the second-line decision-making process remained less clear, and erlotinib (for all NSCLC) as well as afatinib (for squamous cell histology only) have initially been FDA-approved irrespective of EGFR mutational status or other predictive markers $(3,8)$. Several recent prospective clinical trials (TAILOR, DELTA) and retrospective biomarker analyses challenge this broad approval and emphasize the need for EGFR mutational re-testing ahead of the second-line therapy if not performed at diagnosis $(9,10)$.

\section{EVIDENCE FOR CLINICAL EFFICACY OF EGFR TKIS IN THE SECOND LINE}

The use of first-generation EGFR TKIs like erlotinib and gefitinib in the second-line treatment of patients with EGFR-mutant NSCLC is supported by prospective single-arm studies, retrospective biomarker analyses of phase-II studies and subgroup analyses from phase-III studies (11-20). Several randomized trials have compared single-agent EGFR TKIs with single-agent chemotherapy and showed an improvement in progression-free survival (PFS) but mostly not in overall survival (OS) with chemotherapy compared with EGFR TKIs in an EGFR wildtype population $(9,10,19,21-28)$. Afatinib has been tested in the worldwide LUX-Lung trial program and second-line studies included LUX-Lung 2 (first- or second-line, single-arm), LUX-Lung 4 (second-line or beyond), and the head-to-head comparison with erlotinib in LUX-Lung 8 (second-line) $(8,29)$. Afatinib like dacomitinib (the latter is not FDA-approved yet) irreversibly inhibits all ErbB family members and was supposed to overcome resistance mediated by secondary EGFR T790M mutations (30) which occur in $\sim 50-60 \%$ of cases upon progression with reversible EGFR TKIs (31). Both drugs demonstrated promising activity against T790M in preclinical models but failed to overcome T790M-mediated resistance in patients due to doselimiting toxicity resulting from inhibition of wild-type EGFR (32). Furthermore, analyses of small numbers of re-biopsy samples suggest that treatment with afatinib in the first-line results in similar rates ( $50-60 \%)$ of secondary T790M mutations upon progression compared to reversible EGFR TKIs $(31,33)$. This may be due to the high frequency (up to $80 \%$ ) of pretreatment EGFR T790M mutations (34). However, the results from LUXLung 4 and 5 suggested that some patients not only may benefit from afatinib after acquired resistance to gefitinib/erlotinib but also from continued ErbB inhibition during chemotherapy versus switching to single-agent chemotherapy after progression with EGFR TKIs (35). The LUX-Lung 5 results have yet not let to changes in second-line treatment recommendations in terms of combining EGFR inhibition with cytotoxic chemotherapy postprogression in patients with EGFR-mutant NSCLC who initially responded to EGFR TKI treatment.

\section{AFATINIB IN NSCLC WITH SQUAMOUS CELL HISTOLOGY}

Currently, treatment paradigms are most dramatically changing in tumors with squamous cell histology. This entity has unmet medical needs even though the incidence in Western countries is decreasing (25\% of all lung cancer cases). Reflecting the tobacco carcinogenesis, tumors are genomically complex yet EGFR mutations are sporadic, and EGFR molecular testing is not routinely performed in this subgroup (36). Molecular analyses indicated that pan-ErbB blockade could be of therapeutic benefit in squamous cell tumors due to multiple genetic aberrations in ErbB receptors (HER2: 4\%, HER3: 2\%) and in downstream signaling molecules (KRAS: 3\%, HRAS: 3\%, BRAF: 4\%, NF1: $11 \%$, NRG1) (36). Furthermore, $20-30 \%$ of tumors overexpress HER2 and HER3. Whereas erlotinib was the only approved second-line TKI in squamous cell lung cancer since 2004, afatinib received FDA- and EMA-approval for the second-line treatment of squamous cell NSCLC in 2016 based on results of the head-to-head (against erlotinib) study LUX-Lung 8 (8). This approval is irrespective of the intratumoral EGFR mutational status. Supposedly, the improved OS [median 7.9 months (95\% CI 7.2-8.7) versus 6.8 months (5.9-7.8); HR 0.81 (95\% CI $0.69-0.95), p=0.0077$ ] is unlikely driven by the inhibition of mutant EGFR which was found in only $6 \%$ of the patients but rather by the broader irreversible pan-ErbB blockade with afatinib compared to erlotinib.

\section{NEWLY EMERGING THIRD-GENERATION EGFR INHIBITORS AND IMMUNE CHECKPOINT BLOCKADE IN THE SECOND-LINE TREATMENT}

After second-generation EGFR TKIs failed to effectively overcome T790M-mediated resistance in the clinical setting, drugs that specifically inhibit EGFR T790M without affecting wild-type EGFR were developed subsequently. Osimertinib $\left(\right.$ Tagrisso $\left.^{\circledR}\right)$, a EGFR T790M-specific kinase inhibitor, inhibits EGFR exon 18, 19, and 21 mutations and the drug-resistant T790M mutation and received accelerated FDA approval in 2015. Response rates to osimertinib in patients with T790Mpositive tumors after first-generation EGFR TKI are comparable to those with first-line EGFR TKI (58-61\%) and the median PFS reached 9.6 months compared to 2.8 months in EGFR T790Mnegative patients. Osimertinib has a better toxicity profile than first- and second-generation EGFR TKI due to the reduced wild-type EGFR inhibition. Common adverse events are classspecific (i.e., diarrhea, rash, nail toxicity) but were generally mild to moderate (37).

Other promising therapeutic concepts that experienced a tremendous renaissance especially in squamous cell NSCLC include the modulation of the tumor vasculature [anti-VEGFR-2 antibody ramucirumab (Cyramza ${ }^{\circledR}$ ), REVEL trial] (38) and of the immune environment. The latter strategy enhances the patient's natural immune response to cancer mainly via CD8+ cells. Cytotoxic T-lymphocyte-associated protein-4 (CTLA-4) and programmed cell death protein (PD-1) have been identified as important targets which are expressed on activated $\mathrm{T}$ cells and interact with ligands on antigen-presenting cells thereby limiting the immune response. Both, the anti-PD-1 monoclonal antibody Nivolumab $\left(\right.$ Opdivo $\left.^{\circledR}\right)(39,40)$ and pembrolizumab (Keytruda $\left.{ }^{\circledR}\right)(41)$ have 
been FDA-approved for PD-L1-positive (defined as a tumor proportion score $\geq 50 \%$ ) metastatic squamous (nivolumab) or squamous and non-squamous (pembrolizumab) NSCLC lacking $E G F R$ or $A L K$ mutations with progression to platinum-based chemotherapy. Other antibodies targeting PD-L1 like atezolizumab (MPDL3280A) confirm the efficacy of this innovative concept of immune checkpoint blockade (42).

\section{CONCLUSION AND OUTLOOK}

Compared to the their role in the first-line, reversible (erlotinib, gefitinib) and irreversible (afatinib) EGFR TKIs have relatively less impact on the second-line treatment of patients with advanced NSCLC. Afatinib, however, was recently approved for patients with squamous cell NSCLC irrespective of the EGFR mutational status. With the advent of innovative treatment concepts as e.g., immune checkpoint blockade or T790M-specific EGFR inhibition, it is likely that EGFR TKIs will be further pushed into the first-line where they already today face ongoing head-to-head comparisons with the EGFR T790M-specific inhibitor osimertinib to identify the most effective upfront treatment option for patients with EGFR-mutant NSCLC (e.g., FLAURA trial: osimertinib versus gefitinib or erlotinib).

Currently, patients with EGFR-mutant tumors should be treated with EGFR TKIs as soon as possible, ideally in the first-line setting. This is supported by several first-line phase-III clinical trials, which showed higher response rates $(>70 \%)(5,43)$ as if the EGFR TKI was given in the second-line (27-67.4\%) even though some of the reported data on response rates have been conflicting $(5,18,19,43,44)$. Apart from the pooled LUX-Lung 3 and 6 analyses, all EGFR TKI first-line trials failed to show an OS benefit (45). This is likely confounded by crossover of patients to EGFR TKI post-progression to first-line chemotherapy. From the only prospective randomized TORCH trial which compared first-line EGFR TKI followed by chemotherapy with first-line chemotherapy followed by second-line EGFR TKI, the authors concluded, that patients with EGFR mutations would experience greater benefit from first-line EGFR TKI followed by second-line chemotherapy. However, patients in this study were not selected by EGFR mutational status (only $14.2 \%$ were EGFR mutation positive) and the small sample size as well as the fact that only $60 \%$ of patients in both arms received second-line treatment furthermore confounded the result (46). Numerous arguments yet support the application of EGFR TKI in the first-line over second-line: quality of life during EGFR TKI treatment is better compared to first-line chemotherapy especially in patients with poor performance status, whole-brain irradiation with its detrimental consequences on cognitive functions for patients with brain metastasis may be delayed by EGFR TKIs (47-49) and giving EGFR TKIs upfront increases the chance of TKI exposure for those patients whose tumors harbor the target. This is supported by the fact that about $1 / 3$ of patients with EGFR mutations assigned to first-line chemotherapy did not receive EGFR TKI as salvage therapy in IPASS, WJTOG 3405, and OPTIMAL (4, 6, 50). LUX-Lung 6 reported the longest PFS (13.7 months) of all first-line EGFR TKIs and two head-to-head comparison studies [LUX-Lung 7 (first-line) and 8 (second-line)] were slightly in favor of afatinib over erlotinib and gefitinib even though there was some criticism about the interpretation of results and the publication strategy (26). Nevertheless, these trials indicate that afatinib is a highly effective drug in this setting but comes with numerically higher side effect rates compared to erlotinib and gefitinib $(8,51,52)$. These toxicities are effectively manageable by supportive measures $(53,54)$ and tolerability-guided dose reductions which do not affect therapeutic efficacy (55). Especially afatinib, however, will be confronted with EGFR T790M-specific inhibitors like osimertinib in the first-line setting as the latter have a more favorable toxicity profile due to less wild-type EGFR inhibition.

If EGFR mutational testing has not been performed ahead of the first-line therapy-it is estimated that 15 to $35 \%$ of patients have insufficient tumor tissue for genotyping $(56,57)$, patients should be considered for repeated testing before starting second-line therapy. Plasma-genotyping, a technique that uses cell-free (cf)DNA, may be an important alternative to the classical biopsy approach in this scenario $(58,59)$ and it is highly likely that "liquid biopsies" will become available for many known oncogenic and resistance mutations in the near future. This may substantially change the decision-making process as liquid biopsies will enable the physician to monitor development of resistance more promptly and to decide more accurately on therapeutic consequences (60). TAILOR, DELTA, and other trials indicate the predictive value of EGFR mutational status on EGFR TKIs in the second-line $(9,10)$. In particular, the TAILOR study clearly suggests that second-line docetaxel is superior to erlotinib in terms of survival in all patients with EGFR wild-type NSCLC who are able to tolerate toxicities of chemotherapy. DELTA and other trials (CTONG0806 (28) and NCT01783834 (61): pemetrexed versus gefitinib) as well as a meta-analysis by Li et al. (62) point into the same direction with a better PFS for second-line chemotherapy in EGFR wild-type patients. On the contrary, there is evidence to suggest that patients with EGFRmutant NSCLC who are still TKI naive perform better with EGFR TKIs $(9,10,19,21-28)$. In this context, reacting to the JUNO trial results (not fully published yet), FDA restricted the indication for erlotinib as maintenance or second or greater line treatment to those NSCLC patients whose tumors harbor common EGFR mutations in October 2016.

If the EGFR mutation status remains unknown for the secondline treatment decision, a preferred strategy would be to offer nivolumab for squamous NSCLC or pembrolizumab for squamous and non-squamous histology (after platinum-based chemotherapy if $\mathrm{PD}-\mathrm{L} 1$ expression $\geq 50 \%$ ). The approval of immune checkpoint inhibitors will consequently push docetaxel-long the standard of care treatment in the second-line-to the thirdline or even beyond. Especially for squamous cell NSCLC, based on the positive survival results of the SQUIRE study which tested the human EGFR monoclonal antibody necitumumab in combination with cisplatin-gemcitabine chemotherapy, the treatment might soon change even in the first-line setting (63). Big efforts are furthermore ongoing to advance biomarker-driven therapies for patients with squamous cell carcinoma of the lung within the Lung-MAP studies (64) and it is also not a far-fetched vision that immune checkpoint inhibitors will have a role in untreated 
advanced lung cancer. Currently, more than 10 randomized trials (among them KEYNOTE, CHECKMATE, IMPOWER) are ongoing and the question will rather be how checkpoint inhibitors will integrate into the upfront setting, as monotherapy or in concurrent or sequential combination with chemotherapy.

Other important questions remain that may open up new indications for afatinib, but also other EGFR TKIs as to which drug is most effective in controlling brain metastases and rare EGFR mutations. It is known, that patients with EGFR mutations have an increased risk especially for leptomeningeal tumor dissemination $(65,66)$. Penetration of the blood-brain barrier as well as clinical efficacy have been described for both afatinib (47-49) and osimertinib (67). Other EGFR inhibitors with high in vivo CNS penetration (e.g., AZD3759) are currently under early clinical phase evaluation. To determine the most effective drug for CNS disease, also more systematic investigation of the mutational spectrum in brain metastases is required. In this context, surprisingly, a restrospective study found the majority of CNS and leptomeningeal metastases to be negative for EGFR T790M despite of T790M positivity in the extracranial tumor (spatiotemporal heterogeneity) (68). This may argue against T790M-specific and rather for first- or second-generation EGFR TKIs.

Another field of current interest are less common EGFR mutations which together represent about $10 \%$ of all EGFR mutations (69). Especially afatinib may be a good option for these rare EGFR mutations that include exon 18-21 duplications, G719X, Del18, E709K, insertions in exon 19, S768I, or L861Q as erlotinib, osimertinib and gefitinib showed only moderate activities

\section{REFERENCES}

1. Thomas A, Liu SV, Subramaniam DS, Giaccone G. Refining the treatment of NSCLC according to histological and molecular subtypes. Nat Rev Clin Oncol (2015) 12:511-26. doi:10.1038/nrclinonc.2015.90

2. Fossella FV, DeVore R, Kerr RN, Crawford J, Natale RR, Dunphy F, et al. Randomized phase III trial of docetaxel versus vinorelbine or ifosfamide in patients with advanced non-small-cell lung cancer previously treated with platinum-containing chemotherapy regimens. The TAX 320 non-small cell lung cancer study group. J Clin Oncol (2000) 18:2354-62. doi:10.1200/ jco.2000.18.12.2354

3. Shepherd FA, Rodrigues Pereira J, Ciuleanu T, Tan EH, Hirsh V, Thongprasert $\mathrm{S}$, et al. Erlotinib in previously treated non-small-cell lung cancer. $N$ Engl J Med (2005) 353:123-32. doi:10.1056/NEJMoa050753

4. Mok TS, Wu YL, Thongprasert S, Yang CH, Chu DT, Saijo N, et al. Gefitinib or carboplatin-paclitaxel in pulmonary adenocarcinoma. N Engl J Med (2009) 361:947-57. doi:10.1056/NEJMoa0810699

5. Maemondo M, Inoue A, Kobayashi K, Sugawara S, Oizumi S, Isobe H, et al. Gefitinib or chemotherapy for non-small-cell lung cancer with mutated EGFR. N Engl J Med (2010) 362:2380-8. doi:10.1056/NEJMoa 0909530

6. Mitsudomi T, Morita S, Yatabe Y, Negoro S, Okamoto I, Tsurutani J, et al. Gefitinib versus cisplatin plus docetaxel in patients with non-small-cell lung cancer harbouring mutations of the epidermal growth factor receptor (WJTOG3405): an open label, randomised phase 3 trial. Lancet Oncol (2010) 11:121-8. doi:10.1016/S1470-2045(09)70364-X

7. Yang JC, Wu YL, Schuler M, Sebastian M, Popat S, Yamamoto N, et al. Afatinib versus cisplatin-based chemotherapy for EGFR mutation-positive lung adenocarcinoma (LUX-Lung 3 and LUX-Lung 6): analysis of overall survival data from two randomised, phase 3 trials. Lancet Oncol (2015) 16:141-51. doi:10.1016/S1470-2045(14)71173-8 in these mutations $(70,71,72)$. Osimertinib contrariwise may be effective in rare exon 20 insertions whereas nazartinib (EGF816) shows promising efficacy in the majority of exon 20 mutations. The quinazoline-based EGFR inhibitors, gefitinib and afatinib finally proofed efficacy in tumors containing a common EGFR mutation (i.e., Del19 or L858R), in conjunction with L718Q, L844V, or C797S $(73,74)$.

To summarize, treatment paradigms for NSCLC patients in the second-line are currently experiencing dramatic changes. Many of the currently tested innovative concepts will likely move forward to the first-line treatment, whereas other strategies and possibly indications for EGFR TKIs (as, e.g., continued ErbB blockade post-progression, TKI-specific efficacy in rare mutations) may be established in the second-line. One necessity that all therapeutic concepts and treatment lines share in common is the urgent need for reliable predictive factors in times of increasing treatment costs. These are still not available for anti-angiogenic agents like ramucirumab and it remains unclear, if any predictive biomarker will help to select patients with squamous cell NSCLC for afatinib treatment in the future.

\section{AUTHOR CONTRIBUTIONS}

JK wrote the manuscript and is responsible for all its content.

\section{FUNDING}

JK currently receives a Mildred-Scheel Postdoctoral Fellowship from the German Cancer Aid Foundation (Deutsche Krebshilfe).

8. Soria JC, Felip E, Cobo M, Lu S, Syrigos K, Lee KH, et al. Afatinib versus erlotinib as second-line treatment of patients with advanced squamous cell carcinoma of the lung (LUX-Lung 8): an open-label randomised controlled phase 3 trial. Lancet Oncol (2015) 16:897-907. doi:10.1016/ S1470-2045(15)00006-6

9. Garassino MC, Martelli O, Broggini M, Farina G, Veronese S, Rulli E, et al. Erlotinib versus docetaxel as second-line treatment of patients with advanced non-small-cell lung cancer and wild-type EGFR tumours (TAILOR): a randomised controlled trial. Lancet Oncol (2013) 14:981-8. doi:10.1016/ S1470-2045(13)70310-3

10. Kawaguchi T, Ando M, Asami K, Okano Y, Fukuda M, Nakagawa H, et al. Randomized phase III trial of erlotinib versus docetaxel as second- or thirdline therapy in patients with advanced non-small-cell lung cancer: Docetaxel and Erlotinib Lung Cancer Trial (DELTA). J Clin Oncol (2014) 32:1902-8. doi:10.1200/JCO.2013.52.4694

11. Cortes-Funes H, Gomez C, Rosell R, Valero P, Garcia-Giron C, Velasco A, et al. Epidermal growth factor receptor activating mutations in Spanish gefitinib-treated non-small-cell lung cancer patients. Ann Oncol (2005) 16:1081-6. doi:10.1093/annonc/mdi221

12. Han SW, Kim TY, Hwang PG, Jeong S, Kim J, Choi IS, et al. Predictive and prognostic impact of epidermal growth factor receptor mutation in non-small-cell lung cancer patients treated with gefitinib. J Clin Oncol (2005) 23:2493-501. doi:10.1200/JCO.2005.01.388

13. Rosell R, Ichinose $Y$, Taron M, Sarries C, Queralt C, Mendez P, et al. Mutations in the tyrosine kinase domain of the EGFR gene associated with gefitinib response in non-small-cell lung cancer. Lung Cancer (2005) 50:25-33. doi:10.1016/j.lungcan.2005.05.017

14. Hirsch FR, Varella-Garcia M, Bunn PA Jr, Franklin WA, Dziadziuszko R, Thatcher N, et al. Molecular predictors of outcome with gefitinib in a phase III placebo-controlled study in advanced non-small-cell lung cancer. J Clin Oncol (2006) 24:5034-42. doi:10.1200/JCO.2006.06.3958 
15. Sutani A, Nagai Y, Udagawa K, Uchida Y, Koyama N, Murayama Y, et al. Gefitinib for non-small-cell lung cancer patients with epidermal growth factor receptor gene mutations screened by peptide nucleic acid-locked nucleic acid PCR clamp. Br J Cancer (2006) 95:1483-9. doi:10.1038/sj.bjc. 6603466

16. Ahn MJ, Park BB, Ahn JS, Kim SW, Kim HT, Lee JS, et al. Are there any ethnic differences in molecular predictors of erlotinib efficacy in advanced non-small cell lung cancer? Clin Cancer Res (2008) 14:3860-6. doi:10.1158/1078-0432.CCR-07-4608

17. Tamura K, Okamoto I, Kashii T, Negoro S, Hirashima T, Kudoh S, et al. Multicentre prospective phase II trial of gefitinib for advanced non-small cell lung cancer with epidermal growth factor receptor mutations: results of the West Japan Thoracic Oncology Group trial (WJTOG0403). Br J Cancer (2008) 98:907-14. doi:10.1038/sj.bjc.6604249

18. Rosell R, Moran T, Queralt C, Porta R, Cardenal F, Camps C, et al. Screening for epidermal growth factor receptor mutations in lung cancer. $N$ Engl J Med (2009) 361:958-67. doi:10.1056/NEJMoa0904554

19. Douillard JY, Shepherd FA, Hirsh V, Mok T, Socinski MA, Gervais R, et al. Molecular predictors of outcome with gefitinib and docetaxel in previously treated non-small-cell lung cancer: data from the randomized phase III INTEREST trial. J Clin Oncol (2010) 28:744-52. doi:10.1200/ JCO.2009.24.3030

20. Kim ST, Uhm JE, Lee J, Sun JM, Sohn I, Kim SW, et al. Randomized phase II study of gefitinib versus erlotinib in patients with advanced non-small cell lung cancer who failed previous chemotherapy. Lung Cancer (2012) 75:82-8. doi:10.1016/j.lungcan.2011.05.022

21. Kim ES, Hirsh V, Mok T, Socinski MA, Gervais R, Wu YL, et al. Gefitinib versus docetaxel in previously treated non-small-cell lung cancer (INTEREST): a randomised phase III trial. Lancet (2008) 372:1809-18. doi:10.1016/ S0140-6736(08)61758-4

22. Maruyama R, Nishiwaki Y, Tamura T, Yamamoto N, Tsuboi M, Nakagawa $\mathrm{K}$, et al. Phase III study, V-15-32, of gefitinib versus docetaxel in previously treated Japanese patients with non-small-cell lung cancer. J Clin Oncol (2008) 26:4244-52. doi:10.1200/JCO.2007.15.0185

23. Ciuleanu T, Stelmakh L, Cicenas S, Miliauskas S, Grigorescu AC, Hillenbach $\mathrm{C}$, et al. Efficacy and safety of erlotinib versus chemotherapy in second-line treatment of patients with advanced, non-small-cell lung cancer with poor prognosis (TITAN): a randomised multicentre, open-label, phase 3 study. Lancet Oncol (2012) 13:300-8. doi:10.1016/S1470-2045(11)70385-0

24. Sun JM, Lee KH, Kim SW, Lee DH, Min YJ, Yun HJ, et al. Gefitinib versus pemetrexed as second-line treatment in patients with nonsmall cell lung cancer previously treated with platinum-based chemotherapy (KCSG-LU08-01): an open-label, phase 3 trial. Cancer (2012) 118:6234-42. doi:10.1002/cncr.27630

25. Karampeazis A, Voutsina A, Souglakos J, Kentepozidis N, Giassas S, Christofillakis C, et al. Pemetrexed versus erlotinib in pretreated patients with advanced non-small cell lung cancer: a Hellenic Oncology Research Group (HORG) randomized phase 3 study. Cancer (2013) 119:2754-64. doi:10.1002/cncr.28132

26. Lee JK, Hahn S, Kim DW, Suh KJ, Keam B, Kim TM, et al. Epidermal growth factor receptor tyrosine kinase inhibitors vs conventional chemotherapy in non-small cell lung cancer harboring wild-type epidermal growth factor receptor: a meta-analysis. JAMA (2014) 311:1430-7. doi:10.1001/ jama.2014.3314

27. Zhao N, Zhang XC, Yan HH, Yang JJ, Wu YL. Efficacy of epidermal growth factor receptor inhibitors versus chemotherapy as second-line treatment in advanced non-small-cell lung cancer with wild-type EGFR: a meta-analysis of randomized controlled clinical trials. Lung Cancer (2014) 85:66-73. doi:10.1016/j.lungcan.2014.03.026

28. Zhou Q, Cheng Y, Yang JJ, Zhao MF, Zhang L, Zhang XC, et al. Pemetrexed versus gefitinib as a second-line treatment in advanced nonsquamous nonsmall-cell lung cancer patients harboring wild-type EGFR (CTONG0806): a multicenter randomized trial. Ann Oncol (2014) 25:2385-91. doi:10.1093/ annonc/mdu463

29. Katakami N, Atagi S, Goto K, Hida T, Horai T, Inoue A, et al. LUX-Lung 4: a phase II trial of afatinib in patients with advanced non-small-cell lung cancer who progressed during prior treatment with erlotinib, gefitinib, or both. J Clin Oncol (2013) 31:3335-41. doi:10.1200/JCO.2012.45.0981
30. Garuti L, Roberti M, Bottegoni G. Irreversible protein kinase inhibitors. Curr Med Chem (2011) 18:2981-94. doi:10.2174/092986711796391705

31. Yu HA, Arcila ME, Rekhtman N, Sima CS, Zakowski MF, Pao W, et al. Analysis of tumor specimens at the time of acquired resistance to EGFR-TKI therapy in 155 patients with EGFR-mutant lung cancers. Clin Cancer Res (2013) 19:2240-7. doi:10.1158/1078-0432.CCR-12-2246

32. Li D, Ambrogio L, Shimamura T, Kubo S, Takahashi M, Chirieac LR, et al. BIBW2992, an irreversible EGFR/HER2 inhibitor highly effective in preclinical lung cancer models. Oncogene (2008) 27:4702-11. doi:10.1038/ onc. 2008.109

33. Arcila ME, Oxnard GR, Nafa K, Riely GJ, Solomon SB, Zakowski MF, et al. Rebiopsy of lung cancer patients with acquired resistance to EGFR inhibitors and enhanced detection of the T790M mutation using a locked nucleic acid-based assay. Clin Cancer Res (2011) 17:1169-80. doi:10.1158/1078-0432. CCR-10-2277

34. Watanabe M, Kawaguchi T, Isa S, Ando M, Tamiya A, Kubo A, et al. Ultrasensitive detection of the pretreatment EGFR T790M mutation in non-small cell lung cancer patients with an EGFR-activating mutation using droplet digital PCR. Clin Cancer Res (2015) 21:3552-60. doi:10.1158/1078-0432. CCR-14-2151

35. Schuler M, Yang JC, Park K, Kim JH, Bennouna J, Chen YM, et al. Afatinib beyond progression in patients with non-small-cell lung cancer following chemotherapy, erlotinib/gefitinib and afatinib: phase III randomized LUXLung 5 trial. Ann Oncol (2016) 27:417-23. doi:10.1093/annonc/mdv597

36. Cancer Genome Atlas Research Network. Comprehensive genomic characterization of squamous cell lung cancers. Nature (2012) 489:519-25. doi:10.1038/nature11404

37. Janne PA, Yang JC, Kim DW, Planchard D, Ohe Y, Ramalingam SS, et al. AZD9291 in EGFR inhibitor-resistant non-small-cell lung cancer. $N$ Engl J Med (2015) 372:1689-99. doi:10.1056/NEJMoa1411817

38. Garon EB, Ciuleanu TE, Arrieta O, Prabhash K, Syrigos KN, Goksel T, et al. Ramucirumab plus docetaxel versus placebo plus docetaxel for second-line treatment of stage IV non-small-cell lung cancer after disease progression on platinum-based therapy (REVEL): a multicentre, double-blind, randomised phase 3 trial. Lancet (2014) 384:665-73. doi:10.1016/S0140-6736 (14)60845-X

39. Borghaei H, Paz-Ares L, Horn L, Spigel DR, Steins M, Ready NE, et al. Nivolumab versus docetaxel in advanced nonsquamous non-small-cell lung cancer. N Engl J Med (2015) 373:1627-39. doi:10.1056/NEJMoa1507643

40. Brahmer J, Reckamp KL, Baas P, Crino L, Eberhardt WE, Poddubskaya E, et al. Nivolumab versus docetaxel in advanced squamous-cell non-small-cell lung cancer. N Engl J Med (2015) 373:123-35. doi:10.1056/NEJMoa1504627

41. Garon EB, Rizvi NA, Hui R, Leighl N, Balmanoukian AS, Eder JP, et al. Pembrolizumab for the treatment of non-small-cell lung cancer. NEngl J Med (2015) 372:2018-28. doi:10.1056/NEJMoa1501824

42. Fehrenbacher L, Spira A, Ballinger M, Kowanetz M, Vansteenkiste J, Mazieres $\mathrm{J}$, et al. Atezolizumab versus docetaxel for patients with previously treated non-small-cell lung cancer (POPLAR): a multicentre, open-label, phase 2 randomised controlled trial. Lancet (2016) 387:1837-46. doi:10.1016/ S0140-6736(16)00587-0

43. Sugio K, Uramoto H, Onitsuka T, Mizukami M, Ichiki Y, Sugaya M, et al. Prospective phase II study of gefitinib in non-small cell lung cancer with epidermal growth factor receptor gene mutations. Lung Cancer (2009) 64:314-8. doi:10.1016/j.lungcan.2008.09.010

44. Tsao MS, Sakurada A, Cutz JC, Zhu CQ, Kamel-Reid S, Squire J, et al. Erlotinib in lung cancer - molecular and clinical predictors of outcome. N Engl J Med (2005) 353:133-44. doi:10.1056/NEJMoa050736

45. Mok T, Yang JJ, Lam KC. Treating patients with EGFR-sensitizing mutations: first line or second line - is there a difference? J Clin Oncol (2013) 31:1081-8. doi:10.1200/JCO.2012.43.0652

46. Gridelli C, Ciardiello F, Gallo C, Feld R, Butts C, Gebbia V, et al. First-line erlotinib followed by second-line cisplatin-gemcitabine chemotherapy in advanced non-small-cell lung cancer: the TORCH randomized trial. J Clin Oncol (2012) 30:3002-11. doi:10.1200/JCO.2011.41.2056

47. Hochmair M, Holzer S, Burghuber OC. Complete remissions in afatinib-treated non-small-cell lung cancer patients with symptomatic brain metastases. Anticancer Drugs (2016) 27:914-5. doi:10.1097/CAD. 0000000000000410 
48. Schuler M, Wu YL, Hirsh V, O'Byrne K, Yamamoto N, Mok T, et al. Firstline afatinib versus chemotherapy in patients with non-small cell lung cancer and common epidermal growth factor receptor gene mutations and brain metastases. J Thorac Oncol (2016) 11:380-90. doi:10.1016/j.jtho.2015. 11.014

49. Hoffknecht P, Tufman A, Wehler T, Pelzer T, Wiewrodt R, Schutz M, et al. Efficacy of the irreversible ErbB family blocker afatinib in epidermal growth factor receptor (EGFR) tyrosine kinase inhibitor (TKI)-pretreated non-smallcell lung cancer patients with brain metastases or leptomeningeal disease. J Thorac Oncol (2015) 10:156-63. doi:10.1097/JTO.0000000000000380

50. Zhou C, Wu YL, Chen G, Feng J, Liu XQ, Wang C, et al. Erlotinib versus chemotherapy as first-line treatment for patients with advanced EGFR mutation-positive non-small-cell lung cancer (OPTIMAL, CTONG-0802): a multicentre, open-label, randomised, phase 3 study. Lancet Oncol (2011) 12:735-42. doi:10.1016/S1470-2045(11)70184-X

51. Park K, Tan EH, O’Byrne K, Zhang L, Boyer M, Mok T, et al. Afatinib versus gefitinib as first-line treatment of patients with EGFR mutationpositive non-small-cell lung cancer (LUX-Lung 7): a phase 2B, open-label, randomised controlled trial. Lancet Oncol (2016) 17:577-89. doi:10.1016/ S1470-2045(16)30033-X

52. Zhang X, Ran YG, Wang KJ. Risk of severe rash in cancer patients treated with EGFR tyrosine kinase inhibitors: a systematic review and meta-analysis. Future Oncol (2016) 12(23):2741-53. doi:10.2217/fon-2016-0180

53. Lacouture ME, Schadendorf D, Chu CY, Uttenreuther-Fischer M, Stammberger U, O'Brien D, et al. Dermatologic adverse events associated with afatinib: an oral ErbB family blocker. Expert Rev Anticancer Ther (2013) 13:721-8. doi:10.1586/era.13.30

54. Yang JC, Reguart N, Barinoff J, Kohler J, Uttenreuther-Fischer M, Stammberger U, et al. Diarrhea associated with afatinib: an oral ErbB family blocker. Expert Rev Anticancer Ther (2013) 13:729-36. doi:10.1586/era.13.31

55. Yang JC, Sequist LV, Zhou C, Schuler M, Geater SL, Mok T, et al. Effect of dose adjustment on the safety and efficacy of afatinib for EGFR mutation-positive lung adenocarcinoma: post hoc analyses of the randomized LUX-Lung 3 and 6 trials. Ann Oncol (2016) 27(11):2103-10. doi:10.1093/annonc/mdw322

56. Zhu CQ, Da Cunha Santos G, Ding K, Sakurada A, Cutz JC, Liu N, et al. Role of KRAS and EGFR as biomarkers of response to erlotinib in National Cancer Institute of Canada Clinical Trials Group Study BR.21. J Clin Oncol (2008) 26:4268-75. doi:10.1200/JCO.2007.14.8924

57. Kim ES, Herbst RS, Wistuba II, Lee JJ, Blumenschein GR Jr, Tsao A, et al. The BATTLE trial: personalizing therapy for lung cancer. Cancer Discov (2011) 1:44-53. doi:10.1158/2159-8274.CD-10-0010

58. Oxnard GR, Thress KS, Alden RS, Lawrance R, Paweletz CP, Cantarini M, et al. Association between plasma genotyping and outcomes of treatment with osimertinib (AZD9291) in advanced non-small-cell lung cancer. J Clin Oncol (2016) 34:3375-82. doi:10.1200/JCO.2016.66.7162

59. Sacher AG, Paweletz C, Dahlberg SE, Alden RS, O'Connell A, Feeney N, et al. Prospective validation of rapid plasma genotyping for the detection of EGFR and KRAS mutations in advanced lung cancer. JAMA Oncol (2016) 2:1014-22. doi:10.1001/jamaoncol.2016.0173

60. Yanagita M, Redig AJ, Paweletz CP, Dahlberg SE, O’Connell A, Feeney N, et al. A prospective evaluation of circulating tumor cells and cell-free DNA in EGFR mutant non-small cell lung cancer patients treated with erlotinib on a phase II trial. Clin Cancer Res (2016) 22(24):6010-20. doi:10.1158/1078-0432. CCR-16-0909

61. Kim YS, Cho EK, Woo HS, Hong J, Ahn HK, Park I, et al. Randomized phase II study of pemetrexed versus gefitinib in previously treated patients with advanced non-small cell lung cancer. Cancer Res Treat (2016) 48:80-7. doi:10.4143/crt.2014.307

62. Li N, Yang L, Ou W, Zhang L, Zhang SL, Wang SY. Meta-analysis of EGFR tyrosine kinase inhibitors compared with chemotherapy as second-line treatment in pretreated advanced non-small cell lung cancer. PLoS One (2014) 9:e102777. doi:10.1371/journal.pone.0102777

63. Thatcher N, Hirsch FR, Luft AV, Szczesna A, Ciuleanu TE, Dediu M, et al. Necitumumab plus gemcitabine and cisplatin versus gemcitabine and cisplatin alone as first-line therapy in patients with stage IV squamous non-small-cell lung cancer (SQUIRE): an open-label, randomised, controlled phase 3 trial. Lancet Oncol (2015) 16:763-74. doi:10.1016/S1470-2045(15) 00021-2

64. Steuer CE, Papadimitrakopoulou V, Herbst RS, Redman MW, Hirsch FR, Mack PC, et al. Innovative Clinical Trials: The LUNG-MAP Study. Clin Pharmacol Ther (2015) 97:488-91. doi:10.1002/cpt.88

65. Heon S, Yeap BY, Britt GJ, Costa DB, Rabin MS, Jackman DM, et al. Development of central nervous system metastases in patients with advanced non-small cell lung cancer and somatic EGFR mutations treated with gefitinib or erlotinib. Clin Cancer Res (2010) 16:5873-82. doi:10.1158/1078-0432. CCR-10-1588

66. Iuchi T, Shingyoji M, Itakura M, Yokoi S, Moriya $\mathrm{Y}$, Tamura H, et al. Frequency of brain metastases in non-small-cell lung cancer, and their association with epidermal growth factor receptor mutations. Int J Clin Oncol (2015) 20:674-9. doi:10.1007/s10147-014-0760-9

67. Ballard P, Yates JW, Yang Z, Kim DW, Yang JC, Cantarini M, et al. Preclinical comparison of osimertinib with other EGFR-TKIs in EGFR-Mutant NSCLC brain metastases models, and early evidence of clinical brain metastases activity. Clin Cancer Res (2016) 22:5130-40. doi:10.1158/1078-0432.CCR16-0399

68. Hata A, Katakami N, Yoshioka H, Kaji R, Masago K, Fujita S, et al. Spatiotemporal T790M heterogeneity in individual patients with EGFRmutant non-small-cell lung cancer after acquired resistance to EGFR-TKI. J Thorac Oncol (2015) 10:1553-9. doi:10.1097/JTO.0000000000000647

69. Beau-Faller M, Prim N, Ruppert AM, Nanni-Metellus I, Lacave R, Lacroix L, et al. Rare EGFR exon 18 and exon 20 mutations in non-small-cell lung cancer on 10117 patients: a multicentre observational study by the French ERMETIC-IFCT network. Ann Oncol (2014) 25:126-31. doi:10.1093/ annonc/mdt418

70. Kobayashi Y, Togashi Y, Yatabe Y, Mizuuchi H, Jangchul P, Kondo C, et al. EGFR Exon 18 mutations in lung cancer: molecular predictors of augmented sensitivity to afatinib or neratinib as compared with first- or third-generation TKIs. Clin Cancer Res (2015) 21:5305-13. doi:10.1158/1078-0432. CCR-15-1046

71. Banno E, Togashi Y, Nakamura Y, Chiba M, Kobayashi Y, Hayashi H, et al. Sensitivities to various epidermal growth factor receptor-tyrosine kinase inhibitors of uncommon epidermal growth factor receptor mutations L861Q and S768I: what is the optimal epidermal growth factor receptor-tyrosine kinase inhibitor? Cancer Sci (2016) 107:1134-40. doi:10.1111/ cas. 12980

72. Saxon JA, Sholl LM, Janne PA. Brief report: EGFR L858M/L861Q cis mutations confer selective sensitivity to afatinib. J Thorac Oncol (2017). doi:10.1016/j.jtho.2017.01.006

73. Niederst MJ, Hu H, Mulvey HE, Lockerman EL, Garcia AR, Piotrowska Z, et al. The allelic context of the C797S mutation acquired upon treatment with third-generation EGFR inhibitors impacts sensitivity to subsequent treatment strategies. Clin Cancer Res (2015) 21:3924-33. doi:10.1158/10780432.CCR-15-0560

74. Yu HA, Tian SK, Drilon AE, Borsu L, Riely GJ, Arcila ME, et al. Acquired resistance of egfr-mutant lung cancer to a T790M-specific EGFR inhibitor: emergence of a third mutation (C797S) in the EGFR tyrosine kinase domain. JAMA Oncol (2015) 1:982-4. doi:10.1001/jamaoncol.2015.1066

Conflict of Interest Statement: JK received consultant honoraria from Boehringer Ingelheim for writing and publishing two reviews on afatinib unrelated to this article and travel grants from Roche, Amgen, and Lilly. $\mathrm{He}$ currently is a Mildred-Scheel scholar of the German Cancer Aid Foundation (Deutsche Krebshilfe).

Copyright (C) 2017 Köhler. This is an open-access article distributed under the terms of the Creative Commons Attribution License (CC BY). The use, distribution or reproduction in other forums is permitted, provided the original author(s) or licensor are credited and that the original publication in this journal is cited, in accordance with accepted academic practice. No use, distribution or reproduction is permitted which does not comply with these terms. 